\title{
The Implementation of Law Number 16 of 2019 a Case Study of Early Marriage Prevention in Hulu Sungai Utara Regency Indonesia
}

\author{
Irza Setiawan", Agus Sukristyanto, Achluddin Ibnu Rochim \\ Faculty of Social and Political, University of 17 Augustus 1945, Surabaya, Indonesia \\ Email address: \\ irzasetiawanybm@gmail.com (I. Setiawan), agussukris@untag-sby.ac.id (A. Sukristyanto), didin@untag-sby.ac.id (A. I. Rochim) \\ ${ }^{*}$ Corresponding author
}

To cite this article:

Irza Setiawan, Agus Sukristyanto, Achluddin Ibnu Rochim. The Implementation of Law Number 16 of 2019 a Case Study of Early Marriage Prevention in Hulu Sungai Utara Regency Indonesia. Journal of Public Policy and Administration. Vol. 5, No. 3, 2021 , pp. 117-122. doi: $10.11648 /$ j.jppa.20210503.16

Received: September 2, 2021; Accepted: September 22, 2021; Published: September 30, 2021

\begin{abstract}
Early marriage in Hulu Sungai Utara Regency increases from year to year. The cases of marriage dispensation in 2018 were 15 cases and increased to 53 cases in 2019, and up to 168 cases in 2020. Those cases cannot be separated from the impact on revision of the previous Marriage Law where the minimum age of marriage for women is changed from 16 years old to be 19 years old. Of course, this has an impact on the condition of the community in the field. This research used data reduction, data presentation, and drawing conclusions, to sharpen, classify, direct, discard unnecessary, and organize data in such a way that final conclusions can be drawn and verified, by using 11 informants whose implementation results were drawn into a model for preventing early marriage, it was also supported by marriage dispensation data for the last four years and population data in Hulu Sungai Utara Regency. The trigger for early marriage also occurs due to several factors, such as economic problems, education dropouts, morality problems, and community perception. Based on the conclusion, it was found that the models for preventing early marriage are determining an equation perception of implementing early marriage policies, focusing on increasing established family, improving community morality and changing society culture.
\end{abstract}

Keywords: Policy, Implementation, Early Marriage, Marriage

\section{Introduction}

In human life, the mutual attraction to each other is a natural condition that cannot be ruled out. As the embodiment of nature, the relationship between the opposite sex is bound in terms of marriage. As social beings, humans need a partner of life for living together and creating the children. Marriage is the way of human for their existence as social beings. This marriage is expected to be carried out in a long-term process to obtain harmony and peace.

The important of basic marriage was regulated by Indonesian state in Constitution of Republic of Indonesia Number 16 of 2019 [2] concerning Marriage as the realization of State's concern about marriage legal basis. The thing that needs to be considered is the age limit for marriage as stated in article 7 where marriage will be permitted when man and woman have reached 19 years old. If there is a deviation of this age limit provision, the parents of both man and woman can requests a marriage dispensation to the court or other officials.

According to the analysis from this marriage age limit, it cannot be denied that this marriage is realized by early marriage behavior. It is related to modern era where technology is increasingly sophisticated and gives the posible interaction between the opposite sex through social media to create their attraction between men and women at a young age. This is supported by the widespread dating behavior of young people eventhough they are still at school. So, the marriage can occurs on the basis of someone's actions without any maturity or independence behaviour of young people.

The location of this research is located in Hulu Sungai 
Utara Regency which is a part of South Kalimantan province by the distance about 190 KM from Hulu Sungai Utara Regency. Why it is interesting to discuss the behavior of early marriage in Hulu Sungai Utara Regency. It is because of both news television or online media from public relations of Hulu Sungai Utara Regency often claimed that the number of early marriage has been reduced and developed other opinion of early marriage. The result of this opinion, an Award was given by the National News Agency (LKBN) in the form of the 2018 Antara Award to Hulu Sungai Utara Regency Government for successfully suppressing the rate of early marriage.

However, if it is proven by the data, the opposite fact emerges in a very high increase in the number of early marriages. The number of requests for dispensation for marriage increases every year, as the data of marriage dispensation is shown below.

Table 1. Data of Marriage Dispensation.

\begin{tabular}{lllll}
\hline \multirow{2}{*}{ No } & Month & Year & & \\
\cline { 2 - 5 } & & $\mathbf{2 0 1 8}$ & $\mathbf{2 0 1 9}$ & $\mathbf{2 0 2 0}$ \\
\hline 1 & January & - & 1 & 32 \\
2 & February & - & 9 & 17 \\
3 & March & 2 & - & 16 \\
4 & April & 5 & - & 9 \\
5 & May & 1 & - & 4 \\
6 & June & - & - & 2 \\
7 & July & 1 & 1 & 19 \\
8 & August & - & 6 & 17 \\
9 & September & 2 & 4 & 15 \\
10 & October & 3 & 7 & 15 \\
11 & November & 1 & 22 & 13 \\
12 & December & & 3 & 9 \\
& Total & 15 & 53 & 168 \\
\hline
\end{tabular}

Source: Data of Marriage Dispensation Hulu Sungai Utara [3]

In addition, several phenomena of young marriage are found in Hulu Sungai Utara Regency, such as:

1. Hulu Sungai Utara Regency is often promoted succesfully in reducing the number of early marriages and gets the Antara Award. If it is related to the data, there are significant differences between the real condition of early marriage and society opinion (reducing the number of early marriage). Based on the data from Amuntai Religious Court Hulu Sungai Utara Regency, it can be found the increasing number of early marriage behaviour through marriage dispensation from year to year. In 2018, 15 cases are found and it increased in 2019 to be 53 cases and the last data on September 2020 to be 131 cases.

2. The new revision of Law Number 16 of 2019 concerning Marriage on article 7 regarding the minimum age limit for marriage causes a lack of coordination regarding the provisions of age limit regulation between Amuntai Religious Court and Religious Affairs Office in Hulu Sungai Utara Regency whether this is enforced, or still refers to Law Number 1 of 1974 concerning Marriage.

3. The Socialization of Marriage Age Maturation (PUP) that is organized by the Control Population and Planning Familiy Office (DPPKB) of Hulu Sungai Utara Regency which was carried out was not so consistent. The socialization was only limited to convey the ideal age of marriage and it was not included in the focus of Article 7 Law Number 16 of 2019 concerning Marriage as the legal regulations.

4. The high dropout rate in Hulu Sungai Utara Regency has an impact on increasing early marriage behavior. Based on the data of education Hulu Sungai Utara [4] from kemendikbud.go.id in Hulu Sungai Utara Regency, the majority of dropout was taken by Elementary School student and it is higher than Junior High School, Senior High School, (Islamic Senior High School), or Vocational High School sudent.

\section{Literature Review}

This research discusses Young Marriage in Hulu Sungai Utara Regency. Therefore, some previous literature is needed as a comparison to enrich references from this journal.

Robin D. Jackson, Leana A. Bouffard, and Kathleen A. [11] Fox's research published by the journal Criminal Justice Policy Review Volume 25 pages 503-524 in 2014 in their research entitled Putting Policy Into Practice: Examining School Districts' Implementation of Teen Dating Violence Legislation, Texas is a country that has a policy that regulates dating procedures (behavior described before proceeding to marriage), the results of the research shows that there are psychological services to victims of dating violence, but it is not described how the system is carried out such as sampling implemented in Texas schools.

Ahmad Syaeroji [1] in 2018 in a study entitled Implementation of the Marriage Age Maturation Program $(P U P)$ of the National Population and Family Planning Board $(B K K B N)$ in Efforts to Prevent Early Marriage. A study conducted in the Department of Women Empowerment, Child Protection, Population Control and Family Planning (DP3AP2KB), East Lombok Regency, West Nusa Tenggara, $P U P$ (Marriage Age Maturation) exists due to a large number of early marriages in which the reproductive organs are not ready, causing maternal and infant mortality, bleeding during childbirth, low birth weight, premature birth, and other negative impacts. Unfortunately, this research is not combined with a marriage policy in which conditions for young marriage are allowed with certain criteria as regulated in the Marriage Law.

Daniel T. Lichter [5] in 2001 a study entitled Marriage as Public Policy an important finding in the study is that wellbeing is important in marriage. Humam Iskandar [10] in 2017 a study entitled Application of the dispensation for marriage of minors according to positive law in Indonesia, The factors that are the driving force for applying for a marriage dispensation are economic and moral. Teguh Surya Putra [15] in 2013 a study entitled Age of Marriage Dispensation (Study on Implementation of Article 7 Paragraph 2 of Law Number 1 of 1974 in the Religious Court of Malang City important finding of 
dispensation application due to cultural factors of young marriage in society.

Eddy Fadlyana, Shinta Larasaty [8] in 2019 a study entitled Early marriage and its problems, Factors that encourage the rise of early marriage, such as economic motives, the hope of achieving social and financial security after marriage, cause many parents to approve of early marriage. Elisa Seftriyana, Adelina Hasyim, Yunisca Nurmalisa [7] in 2015 a study entitled Implementation of the marriage law on marriage at a young age in the village of pringombo, Marriage at a young age is more likely to occur in rural areas.

Surmiati Ali [14] in 2015 published a study entitled Young Marriage in Indonesia in the Perspective of State and Religion and their issues. The issue of social phenomena related to young marriage in Indonesia is one of the common phenomena in various regions in the country, both in urban and rural areas. This shows the simplicity of the society's mindset which causes social phenomena (early marriages) commonly occur in various regions of the country, both in big cities and in remote areas. The phenomenon of young marriage will have an impact on family life and the quality of Indonesia's human resources. The age of young marriage correlates to the high divorce rate for couples who are still in their teens are not ready to build their home life. Psychologically, they are still not mature enough to think, moreover they tend to be unstable and emotional when problems occur and fight with each other which ultimately leads to divorce. In addition to the many cases of divorce, infant and maternal deaths in cases of young marriage are the highest cases in Indonesia. Therefore, the social phenomenon of young marriage age has been discussed again by various experts and researchers. They tried to review Law No. 11974 article 7 paragraph 1 which states that the minimum age of marriage is 16 years for women and men at the age of 18 years. Therefore, this research explains how the age of early marriage from the perspective of positive state law and Islamic law. There is a difference between religious and state law in looking in reviewing early marriage that occurs in the country. This research combines positive law and religion, but it does not conclude that there is a mediator between the two so that policy and practice can go hand in hand.

Syarifah Salmah [12] in 2016 a study published by Alhiwar Journal of Da'wah Science and Techniques Vol 04 No 07 June 2016 entitled Early Marriage from a Social and Educational Viewpoint. Marriage is an activity that changes something that is forbidden to be halal with the conditions that a valid marriage has been fulfilled, but what has become a phenomenon in Indonesia, especially in South Kalimantan, is the high number of early marriages that occur. This is because there are some arguments from the community that marrying their child immediately then they do not need to take care of their children, it can eliminate the responsibility as a parent if the child is a girl. National Basic Health Research data in 2014, South Kalimantan Province was ranked $2^{\text {nd }}$ after West Java in cases of early marriage at the youngest age between 10-14 years. Based on the National Population and Family Planning Board $(B K K B N)$ data, the number of adolescent families in South Kalimantan is 2483 people with the number of early marriages reaching $18 \%$ of the total number of adolescents aged 14-16 years. This research emphasizes the data but does not explain in detail what solutions should be taken to overcome early marriage.

Based on some previous studies, it can be concluded that sometimes poverty, dropouts, or unwanted pregnancies trigger early marriages. Moreover, from the statements above, the writer intends to discuss research entitled Young Marriage in Hulu Sungai Utara Regency, South Kalimantan, Indonesia using the theory of Dr. 2012: 14).

\section{Methodology}

Sugiyono [13] in 2003 entitled Administrative research methods are equipped with methods R\&D This research used data reduction, data presentation, and drawing conclusions, to sharpen, classify, direct, discard unnecessary, and organize data in such a way that final conclusions can be drawn and verified, by using 11 informants whose implementation results were drawn into a model for preventing early marriage, it was also supported by marriage dispensation data for the last four years and population data in Hulu Sungai Utara Regency.

\section{Early Marriage in Hulu Sungai Utara Regency}

The population of Hulu Sungai Utara Regency, South Kalimantan Province, Indonesia by gender can be seen in the following table:

Table 2. Population.

\begin{tabular}{llll}
\hline District & Male & Female & Total \\
\hline Danau Panggang & 10.332 & 10.182 & 20.514 \\
Paminggir & 4.043 & 3.957 & 8.000 \\
Babirik & 9.776 & 9.636 & 19.402 \\
Sungai Pandan & 13.697 & 13.942 & 27.639 \\
Sungai Tabukan & 7.412 & 7.416 & 14.828 \\
Amuntai Selatan & 15.158 & 14.995 & 30.153 \\
Amuntai Tengah & 25.226 & 25.383 & 50.609 \\
Banjang & 9.470 & 9.223 & 18.693 \\
Amuntai Utara & 10.056 & 10.454 & 20.510 \\
Haur Gading & 8.040 & 8.339 & 16.379 \\
HULU SUNGAI UTARA & 113.200 & 113.527 & 226.727 \\
\hline
\end{tabular}

Source: Hulu Sungai Utara Regency in Number 2021. [9]

The theoretical model used was Dr. Deborah Stone [6] in her book entitled Policy Paradox The Art of Political Decision Making in 2012 explained that in implementation there were five steps that must be analyzed, so referring to the model of Deborah Stone's theory (2012: 14) it can be explained as follows:

1. Equity (a) about how a group in society takes into account a need (b) with what form of election competition. 
2. Efficiency to use the least amount of resources to achieve the same goal, according to (a) who sets the main objectives and how to balance the various objectives, (b) who benefits from the action, and (c) how to define resources while balancing fairness and efficiency.

3. Welfare or Need, according to factors including (a) how it is assessed, (b) outcomes over time, (c) measures of absolute poverty or relative inequality, and (d) debates about 'moral hazard' or the effect of social security on individual motivation.

4. Liberty (a) a general balance between freedom from coercion and freedom from harm caused by others, (b) debates about individual and state responsibilities, and (c) decisions about whose behavior should be changed.

5. Security (a) our ability to quantify risk scientifically (b) threat perception and hazard experience, (c) debate about how much safety risk is tolerable prior to intervention, (d) who is being targeted (e) how to effect control.

Early marriage in Hulu Sungai Utara Regency if it was viewed from the perspective of Equity on the Needs indicator, marriage is indeed a need with various triggers, but in the Office of Women's Empowerment and Child Protection in Amuntai City, Hulu Sungai Utara Regency, the purpose of learning counseling is postponement of marriage if they are too young age, because children's rights are not fulfilled. The counseling process with clients related to pre-marriage by providing material about household and child problems, generally the causes of young marriages occur due to social media factors, lack of family attention, to unwanted pregnancies. And it is undeniable that social media is communication access between men and women as a trigger for relationship patterns that have an effect on feelings that ultimately lead to marriage regardless of age.

The implementation of Law Number 16 of 2019 with a Case Study of Early Marriage Prevention in Hulu Sungai Utara Regency is related to Equity Variables (Justice) in Article 7 Paragraph 1 regarding the minimum age limit for marriage that is 19 years old. According to the real condition, this limitation cannot withstand the needs of the society to get marriage. In result, the number of marriage dispensation is increasing from year to year. Then, according to the competition selection, they are trying to implement this law by counseling the clients in the a single assembly to strengthen them to have a commitment to live together in a household even though they are still young.

Based on the efficiency variable, the goal of reducing the rate of early marriage is not succesfully achieved although by revising the Law of minimum age of marriage to be 19 years old. On the contrary, this has an impact on increasing the number of marriage dispensation although a series of policy has been determined by relevant agencies and the final result is a marriage dispensations. Based on Welfare or Need variable, it is known that every agencies have different assessment of early marriage definition and this has an impact on different result of assessment itself. In addition, the welfare measure is more focused on family establishment in terms of determining the eligibility of a person to commit int the early marriage or not. The welfare measure is also focused on men and women's moral values in their interaction each other directly or through social media that have a big influence on their moral values.

According to Liberty variable, it is known that a couple who carries out early marriage through a marriage dispensation is based on their commitment without any compulsion from parents. The responsibility of the Regional Government is in accordance with their respective authorities in carrying out Law Number 16 of 2019 article 7 paragraph 1, where there are several mechanisms that must be carried out such as counseling, up to a single assembly to get a marriage dispensation. However, the public's interest in early marriage is very large, especially worrying about violating religious norms, so the number of early marriages is being higher. In terms of Security variable, it shows that early marriage have a potential for premature birth of the baby.

The data shows an increase in early marriage from year to year in Hulu Sungai Utara Regency by using a marriage dispensation. There were 15 cases of early marriage in 2018 , 53 cases in 2019 and it still increase up to 168 cases in 2020. Those cases are included in using a marriage dispensation. It can be concluded that the implementation of Law No. 16 of 2019 a case study of early marriage prevention in Hulu Sungai Utara Regency is not good yet.

\section{Early Marriage Prevention Model}

Based on the results of the Implementation of Law No. 16 of 2019 a case study of early marriage prevention in Hulu Sungai Utara Regency by using applied theory from Dr. Deborah Stone (2012: 14), it discovers a model of early marriage prevention based on theoretical reconstruction.

\subsection{Target Group}

Based on the research results of the Implementation of Law Number 16 of 2019 a case study on early marriage prevention, it is known that the main problem of early marriage is the different opinion of target group. Family Learning Center categorized a target group of early marriage who are under 18 years old because they are no longer referred to as children. Then, the Office of Population Control and Family Planning targets the ideal age of marriage for women at least 21 years old while men are 25 years old. The Office of Religious Affairs and the Religious Courts adjust the Marriage Dispensation in accordance with what is regulated by law Number 16 of 2019 article 7 paragraph 1 which a minimum age is 19 years old. This difference opinion of target group causes different thoughts and results in overcoming early marriage. So, the first variable that can be used as a model for preventing early marriage is the same perception to define what a target group in early marriage is. So this definition of target group refers to Law Number 16 in 2019 who are under 19 years old. 


\subsection{Establishment}

Referring to Law Number 16 of 2019 concerning Marriage, article 7 paragraph 1, the clients who are under 19 years old are permitted to apply a Marriage Dispensation. The important question that will be asked by the Religious Courts in single assembly dispensation for marriage is how the client's level of establishment because the establishment is very influential thing to live together in household. In conclusion, the second variable to prevent early marriage is the development of self independence. This proses of developing establishment becomes a benchmark for age maturation dan becomes a prevention of early marriage.

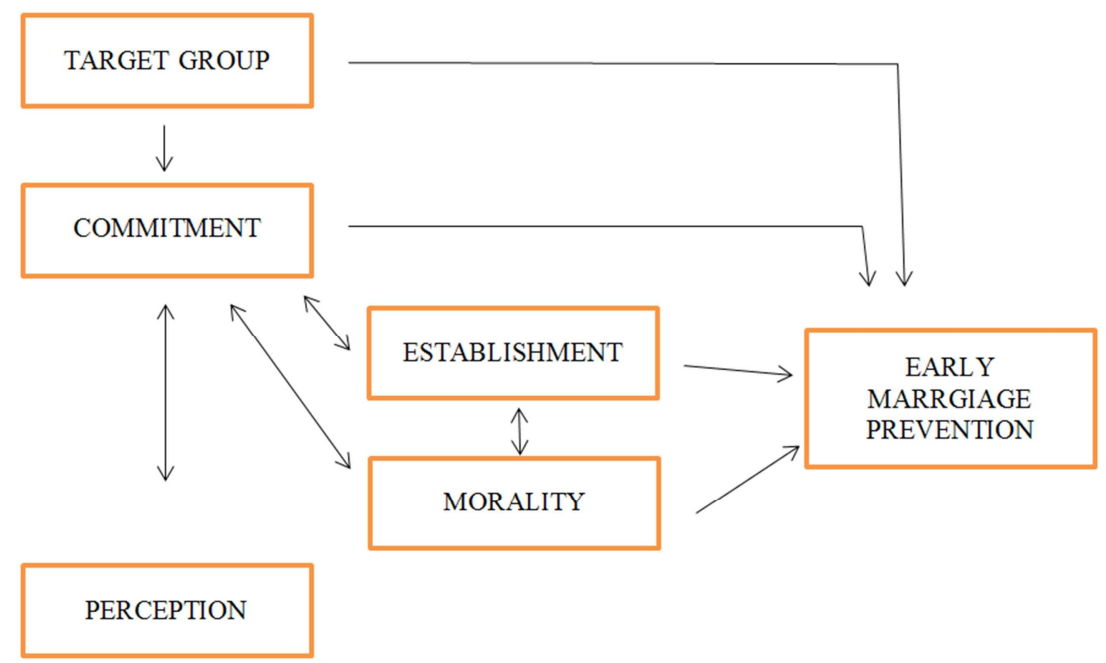

Figure 1. Early Marriage Prevention Model.

\subsection{Morality}

It is undeniable that early marriage can also occurs due to unwanted pregnancy factors and uncontrolled interactions between men and women. This situation also becomes a kind of compulsion to give Marriage Dispensation to clients who apply due to avoid bigger problems. The pattern of moral improvement through religious teachings is very important to prevent moral deviations. Furthermore, parental supervision is also very important especially supervision in social environment and social media. Parental supervision can prevent children from having social media accounts according to platform rules in determining user under 17 years old. So, those actions can give an impact to prevent early marriage.

\subsection{Commitment}

The implementation of Law Number 16 of 2019 a case study of early marriage prevention in Hulu Sungai Utara Regency related to the Liberty variable found that everyone who carries out early marriage through a marriage dispensation is their own commitment without any compulsion from their parents and the responsibility of the Regional Government has been in accordance with their respective authorities in carrying out Law Number 16 of 2019 article 7 paragraph 1, where there are several mechanisms that must be carried out such as counseling, up to a single assembly to get a marriage dispensation. However, the public's interest in early marriage is very large, especially worried violate religious norms, so the number of early marriages is getting higher.
Being free of compulsion and full of responsibility are very important things to strengthen commitment by focusing on improving moral value and religious knowledge (men and women interaction), improving education, and increasing stability. All this aspect becomes a process of their maturity that will have an impact for preventing early marriage.

\subsection{Perception}

People's perceptions about a unemployment children at home and getting married as a solution to help the family's economy must be changed. By socializing the marriage age maturity and positive activites for children, those will have an impact for preventing early marriage.

\section{Conclusion}

The implementation of Law Number 16 of 2019 (A Case Study of Early Marriage Prevention) in Hulu Sungai Utara Regency has not been good. The data shows a significant increase in marriage dispensation. There were 15 cases in 2018 , 53 cases in 2019 and it increased up to 168 cases in 2020. Theoretically, according to the implementation of Dr. Deborah Stone's model (2012: 14) in Equity variable, this limitation cannot prevent the community's needs regarding to get early marriage. The number of marriage dispensations increase from year to year. On the other hand, the competition is still given to implement this law by counseling the clients in a single assembly to strengthen their commitment to live together in household although they are still young.

The reconstuction of Deborah Stone's theory in this Early Marriage Prevention Model is the equation perceptions by 
policy implementers regarding target group with a minimum age of marriage. According to the regulation, Law Number 16 of 2019 concerning the minimum age limit for marriage (19 years old), the commitment will focus on establishment and moral improvement to minimize the early marriage process and reconstruct community culture perception about early marriage as a solution for solving life problem.

\section{References}

[1] Ahmad Syaeroji. (2018). Implementation of the Marriage Age Maturation Program (PUP) of the National Population and Family Planning Board $(B K K B N)$ in Efforts to Prevent Early Marriage. UIN Sunan Kalijaga Journal.

[2] Constitution of Republic of Indonesia Number 16 of 2019.

[3] Data of Marriage Dispensation Hulu Sungai Utara.

[4] Data Of Education Hulu Sungai Utara.

[5] Daniel. T. Lichter (2001). Marriage as public policy. Proggressive Public Institute Journal.

[6] Deborah Stone (2012). Policy Paradox The Art Of Political Decision Making ( $3^{\text {rd }}$ ed.). Norton and Company Wall Strett London.

[7] Elisa Seftriyana, Adelina Hasyim, Yunisca Nurmalisa (2015).
Implementation of the marriage law on marriage at a young age in the village of pringombo. Kultur Demokrasi journal.

[8] Eddy Fadlyana, Shinta Larasaty. (2019). Early marriage and its problems. Sari Petriati Journal.

[9] Hulu Sungai Utara Regency in Number 2021.

[10] Humam Iskandar. (2017). Application of the dispensation for marriage of minors according to positive law in Indonesia (Analytical Study of the Determination of the Bengkulu Religious Court). Qiyas journal.

[11] Robin D. Jackson. Leana A. Bouffard. Kathleen A. Fox. (2014). Putting policy into practice: examining school districts' implementation of teen dating violence legislation. Criminal Justice Policy Review Journal.

[12] Syarifah Salmah. (2016). Early marriage is viewed from a social and educational point of view Alhiwar Journal.

[13] Sugiyono. (2003). Administrative research methods are equipped with methods R \& D. Alfabeta Cv.

[14] Surmiati Ali. (2015). Young Marriage in Indonesia in the Perspective of State and Religion and their issues. FPLP Journal.

[15] Teguh Surya Putra. (2013). Marriage Age Dispensation (Study on Implementation of Article 7 Paragraph 2 of Law Number 1 Year 1974 in the Religious Court of Malang City). Hukum Student Journal. 